\title{
Yttrium Y-90 Tacatuzumab Tetraxetan
}

National Cancer Institute

\section{Source}

National Cancer Institute. Yttrium Y-90 Tacatuzumab Tetraxetan. NCI Thesaurus. Code C48428.

A radioimmunoconjug ate comprised of the humanized monoclonal antibody tacatuzumab, directed against alpha fetoprotein, that is conjug ated to the chelating agent tetraxetan and radiolabeled with the beta-emitting radioisotope Yttrium Y 90. Yttrium Y 90 tacatuzumab tetraxetan binds to tumor cells expressing alpha fetoprotein, thereby selectively delivering a cytotoxic dose of beta radiation. 